\title{
Non-residual heavy metals in Lake Nasser bed sediments, Egypt.
}

\author{
Mohsen M. Yousry \\ Water Research Center, Nile Research Institute, El-Qanater El-Khairiya, Egypt
}

\begin{abstract}
The Present study with the determination of concentrations of non-residual heavy metals (Iron, Manganese, Lead, Cadmium, Chromium, Copper, Nickel and Zinc) in Lake Nasser bed sediments as compared with total heavy metals contents in order to identify their environmental risk in Lake water. The analysis involves testing of sediments collected from eight sampling sites along riverine and transtion zones of Lake Nasser. Organic matter content for each of the sediment samples was also reported to study the effect of its content on the accumulation of metals in bed sediments. It was found that, the non-residual heavy metal levels $\left(\mathrm{mg} \mathrm{kg}^{-1}\right)$ in bed sediments were $0.11 \pm 0.05,13.28 \pm 5.02$, $12.52 \pm 2.89,25.54 \pm 11.1,24.53 \pm 11.29,27.66 \pm 7.29,11610 \pm 2810$ and $418.87 \pm$ 190.91 for $\mathrm{Cd}, \mathrm{Cr}, \mathrm{Pb}, \mathrm{Ni}, \mathrm{Cu}, \mathrm{Zn}, \mathrm{Fe}$ and $\mathrm{Mn}$ respectively. It represents about 20.4, 19.9, 25.2, 38.6, 57.6, 49.3, 41.1 and $45.8 \%$ from the total content of these metals respectively. Fe-Mn oxides and organic matter seem to be the main carrier phases for the non-residual fraction of these metals. The order of non-residual metal concentrations in sediment samples was found to be $\mathrm{Fe}>\mathrm{Mn}>\mathrm{Zn}, \mathrm{Ni}>\mathrm{Cu}>\mathrm{Cr}>\mathrm{Pb}>\mathrm{Cd}$. In the present study, sediment quality assessment was done by calculating sediment pollution index and metal pollution index. The results of the assessment showed that, stream sediments from Lake Nasser are categorized into SPI0 natural sediments in all sites, except one site at km 403 which show SPI1 low polluted sediment. Metal pollution index highlights concentration differences between sites. Moreover, by comparing the results with sediment quality guidelines, it can be found that the $\mathrm{Cd}, \mathrm{Cu}, \mathrm{Zn}, \mathrm{Pb}$ and $\mathrm{Cr}$ levels belong to the concentration below The Effect Range Low (ERL) and the toxicity to the biota in Lake Nasser was rarely occurred. It was also observed that, non-residual heavy metals were found very low compared with the agricultural land use target. This indicates that, Lake Nasser sediment can be used in amendment of agricultural land. The results of this study recommended the use of a pilot project to evaluate the characteristics of sediment for its potential use in agricultural land and to identify how sediments affect the crop yields. Some statistical applications were applied to study the behavior of the metal contents and their correlations in bed sediments.
\end{abstract}

Keywords: Lake Nasser, non-residual metals, bioavailable, metals content, Effect Range Low (ERL). 


\section{INTRODUCTION}

Bioavailability is the proportion of total metals that are available for incorporation into biota (bioaccumulation). Total metal concentrations do not necessarily correspond to metal bioavailability. Bioaccumulation of metals by biota in surface water and by plants and animals in terrestrial environments can adversely affect humans (Davis et al., 1994). Metal toxicity is dependent on its chemical form, mobility, degree of transformation, and bioavailability, which allow metal contaminants to enter the food chain. The contamination of sediment with heavy metals, may lead to serious environmental problem. Heavy metals are widespread pollutants of great environmental concern as they are nondegradable, toxic and persistent with serious ecological ramifications on aquatic ecology (Jumbe and Nandini, 2009). Partition of the total metal concentrations into non-residual and residual fractions or phases is used in sedimentary geochemistry to provide information regarding the binding sites of metals as well as their source and pathways by which they have been transported to the aquatic environment. The non-residual also known as non-lithogenous or nondetrital fraction is considered to be mobile or environmentally reactive fraction in respect of geological and chemical processes. It represents metals that are brought as dissolved or colloidal material, and adsorbed to or precipitated within sediments among different phases, loosely and exchangeable, carbonate, reducible and oxidizable. In contrast, the residual metals (lithogenous) are unlikely to be released into solution through dissolution and remain fixed in sediments within matrix of silicates and other detrital minerals (Jain, 2004).

Analytical data on non-residual heavy metal concentrations are more informative than total metal concentrations in the detection and assessment of pollution, in as much as adsorption, complexation and precipitation are the main forms in which metals from polluting sources are retained in the sediments.

Additionally, the non-residual metal content of sediment is closely related to the labile metal forms. The non-residual metal fraction is more indicative of bioavailable metal than total metal in sediments. It is thought that more information on the extent of metal pollution could be obtained through analysis of this non-residual fraction (Forstner and Wittmann 1979; Doherty et al., 2000).

The chemical and biological processes that affect the mobility depends on environmental factors such as $\mathrm{pH}$, salinity and redox conditions. The most mobile fraction of the sediment is that of the $<63 \mu \mathrm{m}$ grain size. This fraction contains more adsorbed metal/gm of sediment due to its larger surface area.

While both bioavailable and total concentrations of metals are typically studied, yet recently there has been more focus on bioavailable metal forms because these are the ones that have the greatest environmental impact. To determine the mobility of heavy metals in sediments many chemical extraction procedures (single and sequential extractions) have been proposed in the literature. The single leaches (one step) are inexpensive and rapid methods. 
The principle objective of this research is to provide information on secondary and minor non-residual elements in Lake Nasser bed sediments to determine the bioavailabile concentration and their environmental risks in Lake water.

\section{Study area and sampling sites}

\section{MATERIALS AND METHODS}

The study area, im Lake Nasser (Fig. 1), was chosen to start from the Km 347 (Halfa Doghaim) to Km 487.5 (El-Daka) upstream the dam during 2008. This area was chosen as it was counted to be a significant sedimentation zone. Superficial sediment samples were collected from 8 sampling monitored sites along Lake Nasser.

The samples were transferred into labeled polyethylene bags and stored in the laboratory into a freezer until the time of analysis.

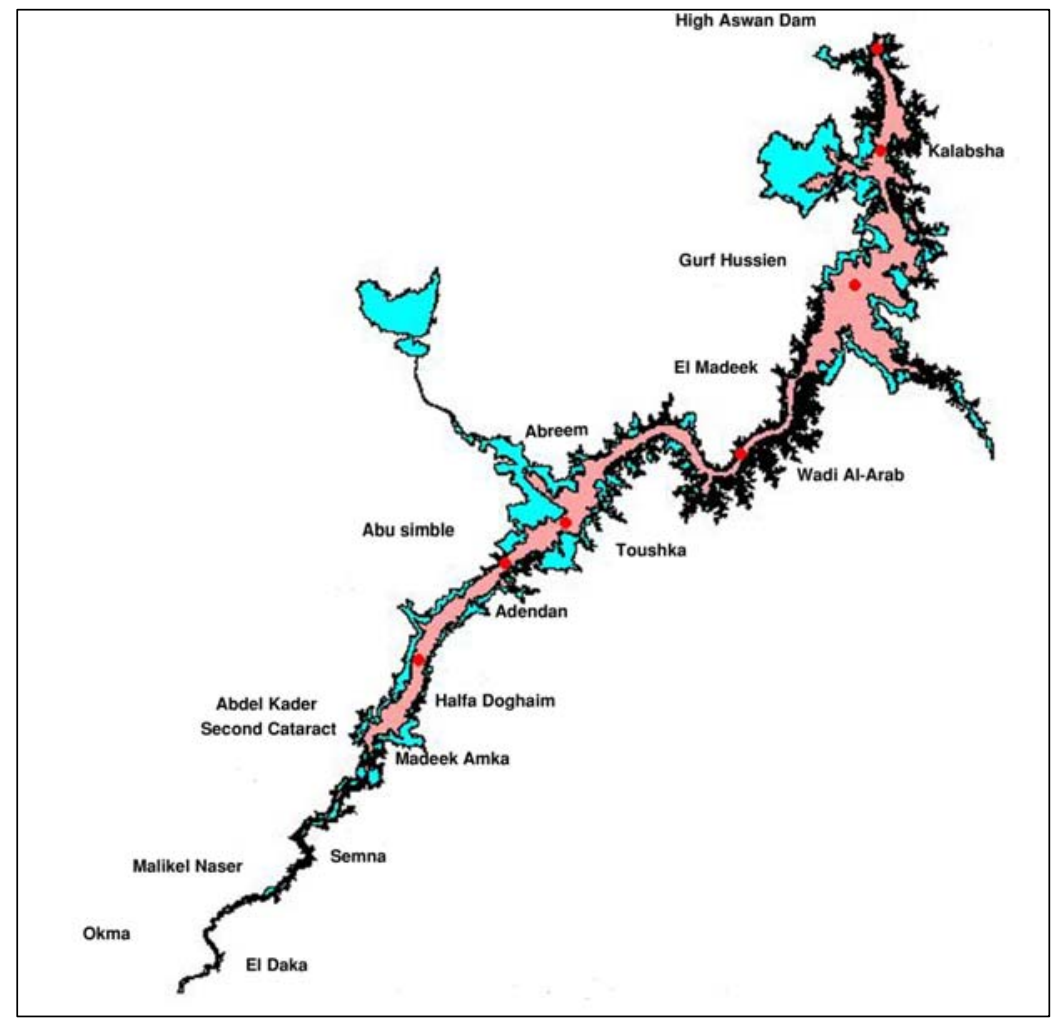

Fig. 1: Map of Lake Nasser showing sampling sites.

\section{Heavy Metals}

The metals studied were iron (Fe), manganese $(\mathrm{Mn})$, nickel $(\mathrm{Ni})$, copper $(\mathrm{Cu})$, lead $(\mathrm{Pb})$, cadmium $(\mathrm{Cd})$, chromium $(\mathrm{Cr})$ and zinc $(\mathrm{Zn})$. In terms of 
toxicity and accessibility, trace metals $\mathrm{Ni}, \mathrm{Cu}, \mathrm{Pb}, \mathrm{Cd}$ and $\mathrm{Cr}$ are toxic and relatively accessible.

\section{Determination of non-residual heavy metals}

In order to minimize interference that may result from grain size variability, only the grain size fraction less than $63 \mu \mathrm{m}$ was considered in this study. The non-residual fraction of metals were extracted by treating one gram sample of sediment with $25 \mathrm{ml}$ of $0.5 \mathrm{M} \mathrm{HCl}$, shaken, filtered through 0.45 micron filter, and the filtrate solution was analyzed for metals (Chester et al., 1985). The extraction removes sorbed metals but does not remove metals from the matrix sediment particles themselves.

This rapid technique has been identified as suitable for the simultaneous extraction of several bound metals, and successfully used to assess non-residual or non-lattice held heavy metals concentration in bed sediments.

\section{Determination of total heavy metals}

Total concentrations of heavy metals were determined by mineralization of $0.5 \mathrm{gm}$ of the sediment $(<63 \mu \mathrm{m})$ using aqua-regia (Binning and Baird, 2001). The concentrations of the elements in the extract solution were determined by ICP-MS.

\section{Determination of organic Matter}

Organic matter content was determined in the same size fraction $(<63 \mu \mathrm{m})$ by means of the widely used potassium dichromate method (Howari et al., 2001).

\section{Assessment of heavy metal concentration}

Two indices were used to assess the metal pollution degree in the sediments these are:

(a) Sediment pollution index (SPI) which calculated according to Singh et al. (2002) and (b) Metal pollution index (MPI) which calculated according to Usero et al. (1996)

\section{Statistical analysis}

Descriptive statistics and correlation matrix were applied using Minitab 12 Software.

\section{Heavy metal concentrations}

\section{RESULTS AND DISCUSSIONS}

Total metal concentrations (summation of residual and non-residual) at different sampling sites are shown in Table (1). It can be seen from the data that the concentrations ( $\mathrm{mg} \mathrm{kg}^{-1}$ ) of the eight metals varied widely as follows: $\mathrm{Cd}$, 0.24-1.10 mg kg${ }^{-1}$; Cr, 55.44-79.8 $\mathrm{mg} \mathrm{kg}^{-1}$; Cu, 32.4-53.88 $\mathrm{mg} \mathrm{kg}^{-1}$; Fe, 23.00$35.05 \mathrm{~g} \mathrm{~kg}^{-1}$; Mn, 496.68-1465.2 mg kg-1; Ni, 37.44-83.76 mg kg-1 Pb, 24.84$92.60 \mathrm{mg} \mathrm{kg}^{-1}$; Zn, 37.44-80.04 mg kg-1. The mean metal concentrations in Lake Nasser decrease in the order $\mathrm{Fe}>\mathrm{Mn}>\mathrm{Cr}>\mathrm{Ni}>\mathrm{Zn}>\mathrm{Pb}>\mathrm{Cu}>\mathrm{Cd}$. 
Table 1: Total heavy metals concentration in bed sediments of Lake Nasser

\begin{tabular}{l|ccccc}
\hline Variables & \multicolumn{5}{|c}{ Total Heavy Metals } \\
& Mean & SD & Range & Minimum & Maximum \\
\hline $\mathrm{Cd}\left(\mathrm{mg} \mathrm{kg}^{-1}\right)$ & 0.54 & 0.33 & 0.86 & 0.24 & 1.10 \\
$\mathrm{Cr}\left(\mathrm{m} \mathrm{kg}^{-1}\right)$ & 66.48 & 8.84 & 24.36 & 55.44 & 79.80 \\
$\mathrm{Cu}\left(\mathrm{mg} \mathrm{kg}^{-1}\right)$ & 42.62 & 10.06 & 21.48 & 32.40 & 53.88 \\
$\mathrm{Fe}\left(\mathrm{g} \mathrm{kg}^{-1}\right)$ & 28.25 & 3.90 & 12.05 & 23.00 & 35.05 \\
$\mathrm{Mn}\left(\mathrm{mg} \mathrm{kg}^{-1}\right)$ & 914.99 & 276.74 & 968.52 & 496.68 & 1465.20 \\
$\mathrm{Ni}\left(\mathrm{m} \mathrm{kg}^{-1}\right)$ & 66.21 & 16.23 & 46.32 & 37.44 & 83.76 \\
$\mathrm{~Pb}\left(\mathrm{mg} \mathrm{kg}^{-1}\right)$ & 49.75 & 24.50 & 67.76 & 24.84 & 92.60 \\
$\mathrm{Zn}\left(\mathrm{mg} \mathrm{kg}^{-1}\right)$ & 56.10 & 13.39 & 42.60 & 37.44 & 80.04 \\
\hline
\end{tabular}

The mean and ranges of non-residual heavy metal concentrations at different sampling sites are reported in Table (2). Evidently, the concentrations of the eight metals varied as follows: Cd, $0.08-0.2 \mathrm{mg} \mathrm{kg}^{-1}$; Cr, 7.36-20.88 mg $\mathrm{kg}^{-1}$; Cu, 10.04-38.04 mg kg-1 Fe, 8.07-15.4 g kg-1 Mn, 181.92-752 mg kg-1 Ni, 14.72-43.36 $\mathrm{mg} \mathrm{kg}^{-1} ; \mathrm{Pb}, 8.16-17.32 \mathrm{mg} \mathrm{kg}^{-1} ; \mathrm{Zn}, 16-36.12 \mathrm{mg} \mathrm{kg}^{-1}$. In addition, the mean concentrations of these metals are $0.11 \mathrm{mg} \mathrm{kg}^{-1} ; 13.28 \mathrm{mg} \mathrm{kg}^{-1} ; 24.53$ $\mathrm{mg} \mathrm{kg}{ }^{-1}$; $11.62 \mathrm{~g} \mathrm{~kg}^{-1}$; $418.87 \mathrm{mg} \mathrm{kg}^{-1}$; $25.54 \mathrm{mg} \mathrm{kg}^{-1} ; 12.52 \mathrm{mg} \mathrm{kg}^{-1}$; and 27.66 $\mathrm{mg} \mathrm{kg}^{-1}$; for $\mathrm{Cd}, \mathrm{Cr}, \mathrm{Cu}, \mathrm{Fe}, \mathrm{Mn}, \mathrm{Ni}, \mathrm{Pb}$ and $\mathrm{Zn}$, respectively. In general, the mean metal concentrations in Lake Nasser sediment decrease in the order $\mathrm{Fe}>\mathrm{Mn}>\mathrm{Zn}, \mathrm{Ni}>\mathrm{Cu}>\mathrm{Cr}>\mathrm{Pb}>\mathrm{Cd}$.

Table 2: Non-residual heavy metals concentration and organic matter content (\%) in bed sediments of Lake Nasser

\begin{tabular}{lccccc}
\hline Variables & Mean & SD & Ron-Residual Heavy Metals & Minimum & Maximum \\
\hline $\mathrm{Cd}\left(\mathrm{mg} \mathrm{kg}^{-1}\right)$ & 0.11 & 0.05 & 0.12 & 0.08 & 0.20 \\
$\mathrm{Cr}\left(\mathrm{m} \mathrm{kg}^{-1}\right)$ & 13.28 & 5.02 & 13.52 & 7.36 & 20.88 \\
$\mathrm{Cu}\left(\mathrm{mg} \mathrm{kg}^{-1}\right)$ & 24.53 & 11.29 & 28.00 & 10.04 & 38.04 \\
$\mathrm{Fe}\left(\mathrm{g} \mathrm{kg}^{-1}\right)$ & 11.61 & 2.81 & 7.33 & 8.07 & 15.40 \\
$\mathrm{Mn}\left(\mathrm{m} \mathrm{kg}^{-1}\right)$ & 418.87 & 190.91 & 570.08 & 181.92 & 752.00 \\
$\mathrm{Ni}\left(\mathrm{mg} \mathrm{kg}^{-1}\right)$ & 25.54 & 11.10 & 28.64 & 14.72 & 43.36 \\
$\mathrm{~Pb}\left(\mathrm{mg} \mathrm{kg}^{-1}\right)$ & 12.52 & 2.89 & 9.16 & 8.16 & 17.32 \\
$\mathrm{Zn}\left(\mathrm{mg} \mathrm{kg}^{-1}\right)$ & 27.66 & 7.29 & 20.12 & 16.00 & 36.12 \\
Organic matter (\%) & 2.59 & 1.28 & 3.38 & 0.62 & 4.00 \\
\hline
\end{tabular}

The partitioning of metals associated with the non-residual fractions (exchangeable and carbonate + reducible + oxidizable) were notably lower than those of the residual fraction except that of $\mathrm{Cu}$ (Fig. 2). 


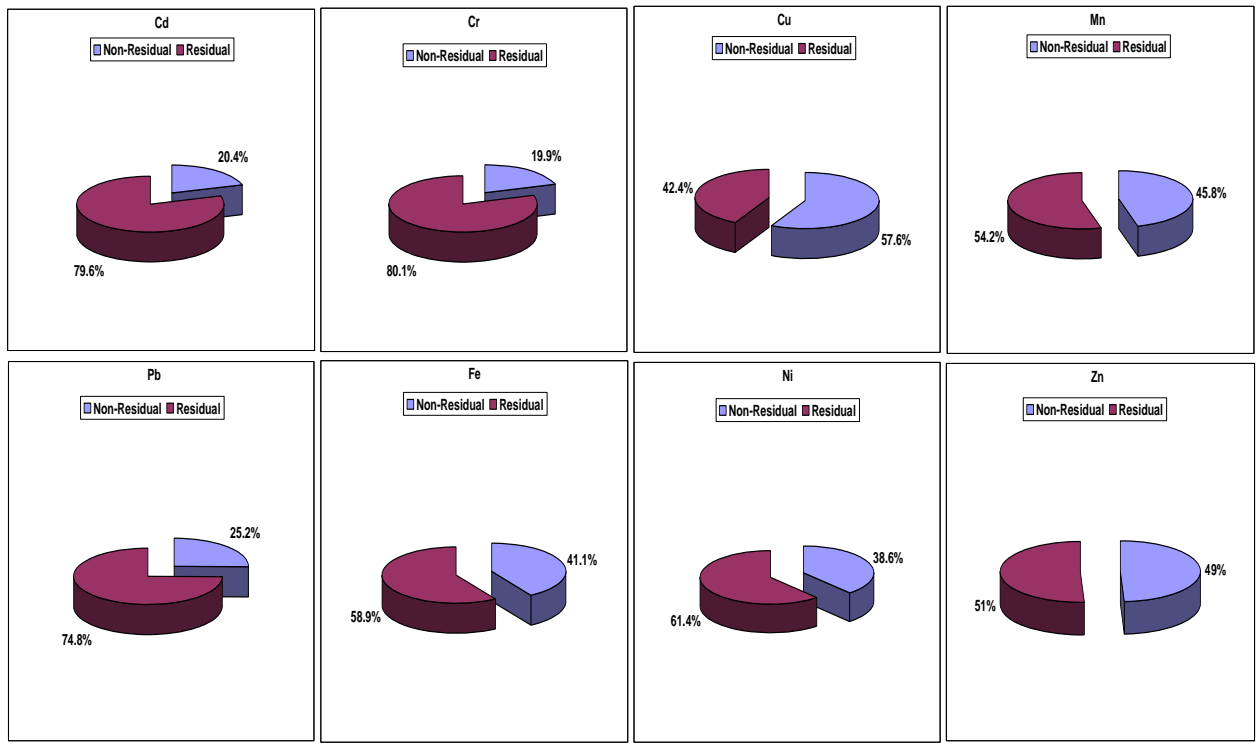

Fig. 2: Percentage of residual and non-residual forms in Lake Nasser sediments

The results indicated that the metals are primarily derived from geochemical background. The high values of $\mathrm{Cu}$ in the non-residual form may be related to the high affinity of $\mathrm{Cu}$ to organic matters, and it could, in fact, easily form complexes with organic matters due to the high stability of organoCu complexes (Li et al., 2001; Ramizer et al., 2005). Several studies have also reported high concentrations of $\mathrm{Cu}$ associated with organic matters in the sediment (Fytianos and Lorantou, 2004; Ramizer et al., 2005; Arias et al., 2007; Wong et al., 2007). The high correlation between copper and organic matter $(\mathrm{r}=0.83)$ was observed in this study (Table 3).

Fortunately, copper mobility is low since the organic fraction released in the oxidizable step is not considered as very mobile or available. According to Sing et al. (1998) copper is thought to be associated with stable high molecular weight humic substances that release small amounts of metals slowly.

Ramos et al. (1999) reported that copper has primarily moved to bind with organic matter. From Table (3), it was also noted that the high correlation between $\mathrm{Zn}$ and $\mathrm{Fe}$ and $\mathrm{Mn}$ support the adsorption of metal on Fe and $\mathrm{Mn}$ oxides, where Zn adsorption onto these oxides has higher stability constants than onto carbonates.

In general, most non-residual metals are associated with organic matter as shown in the correlation matrix. This result is supported by the high organic matter contents along Lake Nasser where, the highest value (4\%) was recorded at Semina site. 
Table 3: correlation matrix between non-residual metals and organic matter (OM) along Lake Nasser

\begin{tabular}{cccccccccc}
\hline & $\mathrm{Cd}$ & $\mathrm{Cr}$ & $\mathrm{Cu}$ & $\mathrm{Fe}$ & $\mathrm{Mn}$ & $\mathrm{Ni}$ & $\mathrm{Pb}$ & $\mathrm{Zn}$ & $\mathrm{OM}$ \\
\hline $\mathrm{Cd}$ & 1 & & & & & & & & \\
$\mathrm{Cr}$ & 0.85 & 1 & & & & & & & \\
$\mathrm{Cu}$ & 0.38 & 0.72 & 1 & & & & & & \\
$\mathrm{Fe}$ & 0.52 & 0.88 & 0.85 & 1 & & & & & \\
$\mathrm{Mn}$ & 0.09 & 0.36 & 0.88 & 0.52 & 1 & & & & \\
$\mathrm{Ni}$ & 0.91 & 0.94 & 0.58 & 0.76 & 0.26 & 1 & & & \\
$\mathrm{~Pb}$ & 0.52 & 0.49 & -0.13 & 0.31 & -0.46 & 0.53 & 1 & & \\
$\mathrm{Zn}$ & 0.49 & 0.81 & 0.86 & 0.81 & 0.69 & 0.64 & 0.15 & 1 & \\
$\mathrm{OM}$ & 0.58 & 0.70 & 0.83 & 0.68 & 0.78 & 0.73 & 0.07 & 0.71 & 1 \\
\hline
\end{tabular}

The role of organic matter in relation to the accumulation of heavy metal to the sediment has been emphasized (Davies et al., 1991). In general, organic matter and clay texture play an important role in controlling heavy metal concentrations in bottom sediments. Gaiero et al. (1997) stated that, the organic matter exhibited a closer correlation with metals probably caused by a larger capacity for complexation in the biologically processed organic debris. The behaviour of natural organic matter may be the single most important influence on trace metal cycling in aquatic systems (Barry, 1982).

In the present study, all heavy metals are relatively stable where the metals are associated with the residual form and the sediment is relatively unpolluted. Our results are substantiated by Heikal (2008) who reported that most metals in Lake Nasser bed sediment have primarily moved to bind with organic and residual forms. Several authors (Davidson et al., 1994; Akcay et al., 2003) have confirmed that the high proportion of metals in the residual fraction indicate that the sediment is relatively unpolluted.

\section{Environmental Assessment}

In this study, two methods were applied for assessing the non-residual metals pollution in the bottom sediments along Lake Nasser. The first assessment was conducted by comparing the average non-residual heavy metals concentration with different sediment quality guidelines (Tables $4 \& 5$ ). Another assessment was applied using certain indices to assess the environmental impacts as mentioned on the methodology.

\section{Ecological health guidelines}

To estimate the possible environmental consequences of the metal analyses, the results were compared with different sediment quality guidelines. In this study the Effect Range Low (ERL) and Effect Range Median (ERM) are considered. The ERL represents chemical concentration below which adverse biological effects were rarely observed, while the ERM represents concentrations above which effects were more frequently observed. Generally, adverse effects occurred in less than $10 \%$ of studies in which concentrations were below the respective ERL values, and were observed in more than $75 \%$ of studies in which concentrations exceeded ERM values (Long et al., 1997). 
Comparing our data with ERL and ERM values (Table 4), all metals, apart from $\mathrm{Ni}$, show lower concentrations than ERL. In case of $\mathrm{Ni}$, it belongs to the concentration between ERL and ERM and represents a probable effects range within which effects would frequently occur ( $>10 \%)$.

Table 4: Comparison between non-residual metals and sediment quality guidelines

\begin{tabular}{cccc}
\hline \multirow{2}{*}{ Element } & \multicolumn{2}{c}{ Guideline (mg/kg) } & \multirow{2}{*}{ Non-Residual metals } \\
& ERL & ERM & 27.66 \\
$\mathrm{Zn}$ & 150 & 410 & 12.52 \\
$\mathrm{~Pb}$ & 47 & 220 & 24.53 \\
$\mathrm{Cu}$ & 34 & 270 & 13.28 \\
$\mathrm{Cr}$ & 81 & 370 & 0.11 \\
$\mathrm{Cd}$ & 1.2 & 9.6 & 25.54 \\
$\mathrm{Ni}$ & 21 & 52 & \\
\hline
\end{tabular}

Generally, the concentrations of non-residual heavy metals were found very low as compared with the agriculture land use values (Canadian environmental quality guidelines 2002) Table 5.

Table 5: Quality objectives for heavy metals in sediments of fresh water

\begin{tabular}{|c|c|c|c|c|c|c|}
\hline Quality objective & $\mathrm{Zn}$ & $\mathrm{Pb}$ & $\mathrm{Cu}$ & $\mathrm{Cr}$ & $\mathrm{Cd}$ & $\mathrm{Ni}$ \\
\hline Nasser Lake & 27.66 & 12.52 & 24.53 & 13.28 & 0.11 & 25.54 \\
\hline Agr. Land use & 200 & 70 & 63 & 64 & 1.4 & 50 \\
\hline
\end{tabular}

\section{Metal Pollution Index}

To compare the content of non-residual metals at the different sampling sites, the metal pollution index was used (Figure 3). This index was used to discriminate between the location where the highest concentration of metals were recorded at $\mathrm{Km} 403$ (Semina) and 368 (Madeek Amka) while the lowest concentration of metals was recorded at Km 487.5 (El-Daka).

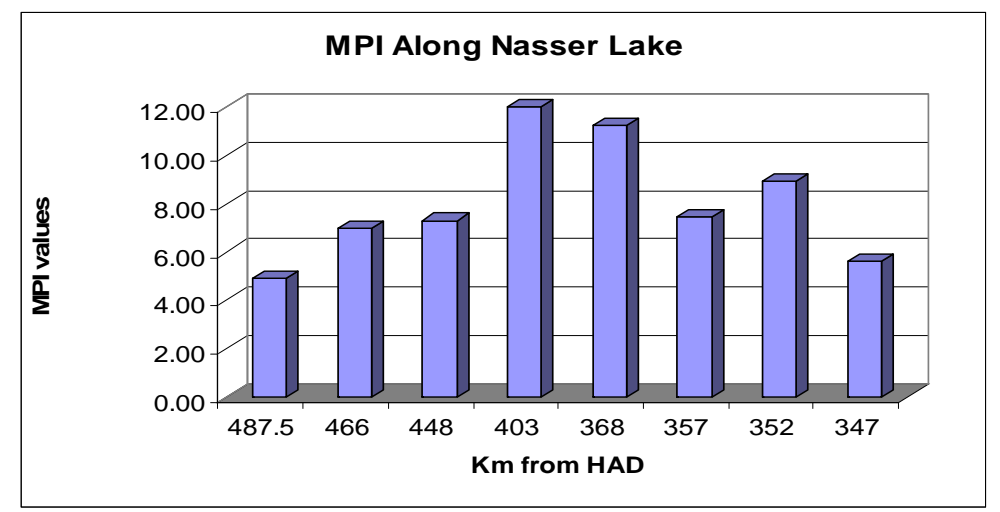

Fig. 3: Metal pollution index (MPI) for each sampling site 


\section{Sediment Pollution Index (SPI)}

A multi-metal approach has been introduced for an overall assessment of sediment quality with respect to heavy metals concentrations along with proper consideration to the relative metal toxicity.

Sediment pollution index has a set of five classes (SPI0-SPI4) ranging qualities from natural to dangerous levels. These classes are SPI0-natural sediment (0-2), SPI1-low polluted sediments (2-5), SPI2-moderately polluted sediments (5-10), SPI3-highly polluted sediments (10-20) and SPI4-dangerous sediments (>20) along with their range. Figure (4) shows the variation in SPI classes of the Lake Nasser . Stream sediments from Lake Nasser are categorized into SPI0 natural sediments in all sites except one site at km 403 which shows SPI1 and classified as low polluted sediment.

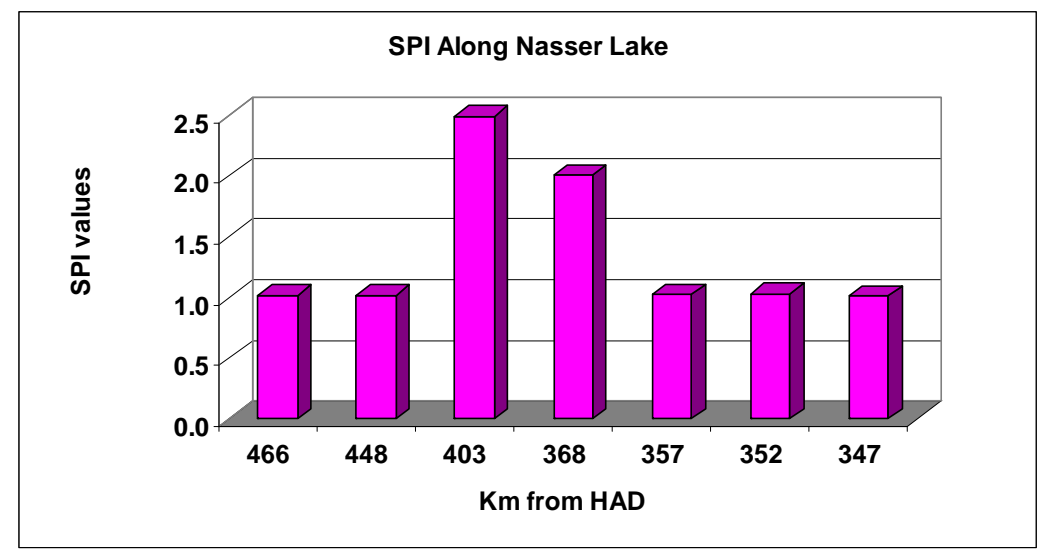

Fig. 4: Sediment pollution index (SPI) for each sample site

\section{Conclusions and Recommendations Conclusions}

The percentage of non-residual heavy metals compared with total heavy metals along Lake Nasser ranged from $19.9 \%$ for $\mathrm{Cr}$ to $57.6 \%$ for $\mathrm{Cu}$. The order of non-residual metal concentrations in sediment samples was found to be $\mathrm{Fe}>\mathrm{Mn}>\mathrm{Zn}>\mathrm{Ni}>\mathrm{Cu}>\mathrm{Cr}>\mathrm{Pb}>\mathrm{Cd}$.

Comparing the results with sediment quality guidelines, it can be found that the levels of $\mathrm{Cd}, \mathrm{Cu}, \mathrm{Zn}, \mathrm{Pb}$ and $\mathrm{Cr}$ belong to the concentration below the effect range low (ERL). It can be concluded that, toxicity to the biota in Lake Nasser rarely occur. It was also observed that, non-residual heavy metals were found very low compared with the agricultural land use target. This indicates that, Lake Nasser sediment can be used in amendment of agricultural land.

Fe-Mn oxides and organic matter seem to be the main carrier phases for the non-residual fraction of these metals. 
Toxic metals like $\mathrm{Cd}, \mathrm{Pb}$ and $\mathrm{Cr}$ are relatively stable where the metals are associated with the residual form and the sediment is relatively unpolluted.

The results of the assessment showed that, stream sediments from Lake Nasser are categorized into SPI0 natural sediments in all sites except one site at $\mathrm{km} 403$ which show SPI1 low polluted sediment. Metal pollution index highlights concentration differences between sites.

\section{Recommendations}

It is recommended to implement a pilot project to evaluate the characteristics of sediment for its potential use in agricultural land reclamation and to identify how the sediments affect the crop yields.

\section{REFERENCES}

Akcay, H.; Oguz, A. and Karapirec, C. (2003). Study of heavy metal pollution and speciation in BuyakMenderes and Gediz River sediments. Water Res., 37:813-822.

Arias, R.; Barona, A.; Ibarra-Berastegi, G.; Aranguiz, I. and Elias. A (2007). Assessment of metal contamination in dredged sediments using fractionation and self-organizing map, J. Haz. Mater, 151: 78-85.

Barry, T.H. (1982). "Uptake of trace metals by sediments and suspended particulates: a review” Hydrobiol, 91-92 (1): 299-313.

Binning, K. and Baird, D. (2001). Survey of heavy metals in the sediments of the Swartkops River Estuary, Port Elizabeth South Africa. Water SA, 27 (4): 461-466.

Chester, R.; Kudoja, W. M.; Thomas, A. and Towner, J. (1985). Environ. Pollut. (Ser. B), 10: 213.

Davidson, C.M.; Thomas, R.P.; McVey, S.E.; Perala, R.; LittleJohn, D. and Ure, A.M. (1994). Evaluation of a sequential extraction procedure for the speciation of heavy metals in sediments. Anal Chim Acta, 291:277286.

Davies, C.A.; Tomljnson, K. and Stephenson, T. (1991). Heavy metals in River estuary sediments. Environ. Technol., 12: 961-972.

Davis, Andy; Ruby, M.V. and Bergstrom, P. D. (1994). Factors controlling lead bioavailability in the Butte mining district, Montana, USA: Environmental Geochemistry and Health, 3/4: 147-157. 
Doherty, G.; Brunskill, G. and Ridd, M. (2000). Natural and enhanced concentrations of trace metals in sediments of Cleveland Bay, Great Barrier Reef Lagoon, Australia. Mar. Poll. Bull., 41: 337-344.

Forstner, U. and Wittmann, G. (1979). Metal pollution in the Aquatic Environment. Springer, Berlin., 486 pp.

Fytianos, K. and Loranton, N (2004). Speciation of elements in sediment samples collected al lakes Volvi and Koronia, N. Greece, Environ., Internat., 20: 11-17.

Gaiero, D. M.; Ross, G. R.; Depetris, P. J. and Kempe, S. (1997). Spatial and temporal variability of total non-residual heavy metals content in stream sediments from the Suquia River system, Cordoba, Argentina. Water, Air, and Soil Pollution, 93:303-319.

Heikal, M. T. (2008). Assessment of heavy metals mobility in Lake Nasser sedimentation. J. Water. Sci., 44: 13-25.

Howari, F. M. and Banat, K. M. (2001). Assessment of Fe, Zn, Cd, Hg, and Pb in the Jordan and Yarmouk River sediments in relation to their physicochemical properties and sequential extraction characterization. Water, Air and Soil Pollution 132: 43-59.

Jain, C. K. (2004). Metal fractionation study on bed sediments of River Yamuna, India. Wat. Res., 38: 569-578.

Jumbe, A. S. and Nandini, N. (2009). Impact assessment of heavy metals pollution of Vartur Lake, Bangalore. J. Applied Nat. Sci., 1:53-61.

Li, X.D.; Shen, Z. G.; Wai, W. H. O. and Li, Y. S. (2001). Chemical forms pf $\mathrm{Pb}, \mathrm{Zn}$ and $\mathrm{Cu}$ in the sediment profile of the Pearl River Estuary, Mar. Pollut. Bull., 42 (3): 215-223.

Long, E. R.; Field, L. J. and Macdonald, D. D. (1997). Predicting toxicity in marine sediments with numerical sediment quality guidelines. Environ, Toxicol. Chem., 17 (4): 714-727.

Ramirez, M.; Serena, M.; Frache, R. and Correa, J. (2005). Metal speciation and environmental impact on sandy beaches due to El Salvador copper mine, Chile, Mar. Pollut. Bull., 50: 62-72.

Ramos, L.; Gonzalez, M. J. and Hernandez, L. M. (1999). Sequential extraction of copper, lead, cadmium and zinc in sediments from Ebro River Spain: 
relationship with levels detected in earthworms, Bull. Environ. Contamin. Toxico., 63: 301-308.

Sing, S. P.; Tack, F. M. and Verloo, M. G. (1998). Heavy metal fractionation and extractability in dredged sediment derived surface soil, water Air Soil Pollut., 102: 313-328.

Singh, M.; Müller, G. and Singh, I. B. (2002). "Heavy metals in freshly deposited stream sediments of rivers associated with urbanisation of the Ganga plain, India” Water-Air-and Soil pollution, 141: 35-54.

Usero, J.; Gonzalez-Regalado, E. and Gracia, I. (1996). Trace metals in the bivalve mollusk Chamelea gallina from the Atlantic Coast of Southern Spain. Mar. Pollut. Bull., 32 (3): 305-310.

Wong, C. S. C.; Wu, S. C.; Duzgoren-Aydin, N. S.; Aydin, A. and Wong, M. H. (2007). Trace metals contamination of sediments in an e-waste processing village in China, Environ. Pollut., 145: 434-442. 